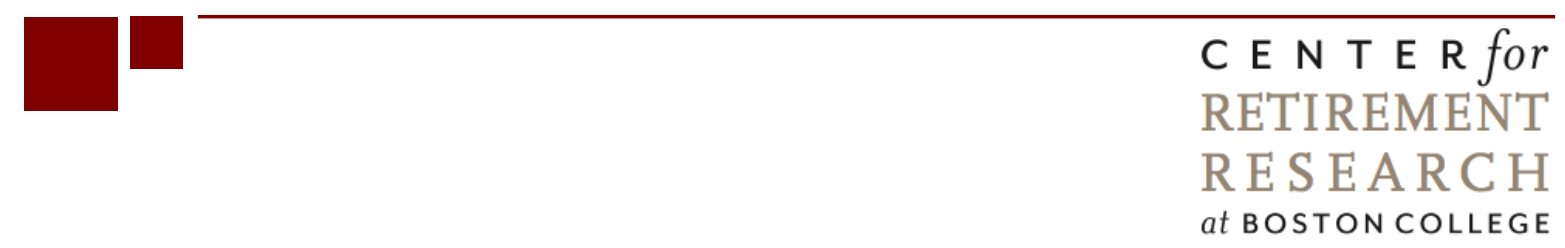

\title{
GEOGRAPHIC MOBILITY AMONG RESIDENTS IN SENIORS HOUSING AND CARE COMMUNITIES: EVIDENCE FROM THE RESIDENTS FINANCIAL SURVEY
}

\author{
Norma B. Coe and April Yanyuan Wu
}

CRR WP 2012-9

Date Released: April 2012

Date Submitted: November 2011

\author{
Center for Retirement Research at Boston College \\ Hovey House \\ 140 Commonwealth Avenue \\ Chestnut Hill, MA 02467 \\ Tel: 617-552-1762 Fax: 617-552-0191 \\ http://crr.bc.edu
}

Norma B. Coe is associate director for research at the Center for Retirement Research at Boston College (CRR). April Yanyuan Wu is a research economist at the CRR. The research reported here was performed pursuant to a grant from the National Investment Center for the Seniors Housing \& Care Industry (NIC), the Assisted Living Federation of America (ALFA), and the American Seniors Housing Association (ASHA). The opinions and conclusion expressed are solely those of the authors and do not represent the opinions or policy of NIC, ALFA, ASHA, or Boston College. The authors are grateful for comments supplied on an earlier draft by Charles Harry. They would also like to thank the team at ProMatura Group, LLC, especially Edie Smith and Margaret Wylde, and Mashfiqur Khan, Madeline Medenica and Zhenya Karamcheva for research assistance. All errors are their own.

Corresponding author: Norma B. Coe, Center for Retirement Research at Boston College, Hovey House, 258 Hammond St., Chestnut Hill, MA 02467; Tel: (617) 552-1762;

Fax: (617) 552-0191; e-mail: Norma.Coe@bc.edu

(C) 2012, Norma B. Coe and April Yanyuan Wu. All rights reserved. Short sections of text, not to exceed two paragraphs, may be quoted without explicit permission provided that full credit, including (C) notice, is given to the source. 


\title{
About the Center for Retirement Research
}

The Center for Retirement Research at Boston College, part of a consortium that includes parallel centers at the University of Michigan and the National Bureau of Economic Research, was established in 1998 through a grant from the Social Security Administration. The Center's mission is to produce first-class research and forge a strong link between the academic community and decision-makers in the public and private sectors around an issue of critical importance to the nation's future. To achieve this mission, the Center sponsors a wide variety of research projects, transmits new findings to a broad audience, trains new scholars, and broadens access to valuable data sources.

\author{
Center for Retirement Research at Boston College \\ Hovey House \\ 140 Commonwealth Avenue \\ Chestnut Hill, MA 02467 \\ phone: 617-552-1762 fax: 617-552-0191 \\ e-mail: crr@bc.edu \\ crr.bc.edu
}

Affiliated Institutions:

The Brookings Institution

Massachusetts Institute of Technology

Syracuse University

Urban Institute 


\section{TABLE OF CONTENTS}

$\begin{array}{ll}\text { 1. Introduction } & \text { Page } 4\end{array}$

$\begin{array}{lll}2 . & \text { Prior Living Arrangements } 4\end{array}$

$\begin{array}{ll}\text { 3. Recent Movers } & \text { Page } 6\end{array}$

$\begin{array}{lll}\text { 4. Short-distance vs. Long-distance Movers } & \text { Page } 8\end{array}$

$\begin{array}{lll}\text { 5. Future Living Arrangements } & \text { Page } 9\end{array}$

$\begin{array}{lll}\text { 6. Conclusions } & \text { Page } 11\end{array}$

$\begin{array}{lll}\text { 7. } & \text { References }\end{array}$

\section{ASSOCIATED PAPERS}

1. Coe, Norma B. and April Yanyuan Wu. 2012. "Residents in Seniors Housing and Care Communities: Overview of the Residents Financial Survey.” Working Paper 2012-6. Chestnut Hill, MA: Center for Retirement Research at Boston College.

2. $\quad$ Coe, Norma B. and April Yanyuan Wu. 2012. "Financial Well-Being of Residents in Seniors Housing and Care Communities: Evidence from the Residents Financial Survey." Working Paper 2012-7. Chestnut Hill, MA: Center for Retirement Research at Boston College.

3. Coe, Norma B. and April Yanyuan Wu. 2012. "Costs and Concerns Among Residents in Seniors Housing and Care Communities: Evidence from the Residents Financial Survey." Working Paper 2012-8. Chestnut Hill, MA: Center for Retirement Research at Boston College. 


\section{Introduction}

There is relatively little known about the geographic mobility of the elderly in general. Despite the stereotype of retiring in Florida, recent work has documented very little home equity changes among the elderly (Venti and Wise 2002, 2004; Anderson, French, and Lam 2004; Fisher et al. 2007), and that most home equity changes are precipitated by a major life event, such as a spouse passing or entry into a nursing home. Haverstick and Zhivan (2009) find that the 2-year moving rate for homeowners is less than 10 percent, and that most of those moves are short-distance (less than 20 miles).

There is even less known in the academic realm about the geographic mobility of individuals who choose to move to Independent Living (IL) or Assisted Living (AL) communities. These communities offer services in addition to housing, such as group meals or activities, help with medication, and often have nursing staff on location. Research to date has been limited by data constraints. To help fill this void, we designed and conducted a new survey, the Residents Financial Survey (RFS), with assistance from ProMatura Group, LLC, to obtain a current economic profile of individuals living in ALs and ILs. ${ }^{1}$ This survey gathered information on the income and assets at the time of the survey (2011), as well as retrospective information concerning living arrangements, care provision, and financial gifts given. The final sample consists of 2,617 respondents living in freestanding ILs, freestanding ALs, and communities that offer both IL and AL arrangements.

This paper explores the geographic mobility patterns of individuals in IL and AL communities using the RFS. We find there is substantial mobility among respondents. We explore the factors that relate to their decisions of moving to a community, moving across communities, and moving out of their current community by investigating the prior living arrangements, characteristics of recent movers, the differences between short- and long-distance movers, and the plans to move in the future.

\section{Prior Living Arrangements}

The vast majority (80-90 percent) of respondents previously lived by themselves or only with their spouses, with the number being slightly higher for those in the IL portion of IL/ALs

\footnotetext{
${ }^{1}$ See Coe and Wu (2012) for more details of the survey.
} 
and lower for freestanding AL residents (Table 1$).^{2}$ More than one-half of residents in freestanding ALs received regular assistance during the six months before moving to the community, while this was true for only 15 percent of respondents living in the IL portion of IL/ALs. While many report receiving assistance before moving in, they were largely not living with family, friends, or a caregiver.

Interestingly, there is considerable inter-community movement. Close to 30 percent of residents in freestanding ALs lived in another community beforehand, with the number being somewhat lower for residents in freestanding ILs (about 19 percent). Using self-reported and community-reported location and zip code information, we calculated whether people moved across state lines as well as computed the distance people moved between their previous location and their current community. ${ }^{3}$ While they tend to stay within their state - only 15 to 20 percent move across state lines, depending on the community type - people are moving quite far, in fact. While the median distance moved is less than 10 miles, the average distance is $150-175$ miles. A close look at the data also shows that a handful of residents moved from other countries, including England, France, Mexico, and Italy. ${ }^{4}$

Despite the fact that AL residents are in poorer health, the respondents living in freestanding ILs had actually been living in the community longer. These respondents reported living in ILs for more than 3.5 years, on average. The respondents from the other living arrangements had moved there six months later, on average. Compared to the NIC (1998) and ALFA (1998), our residents in the AL communities have lived there longer.

In Table 2, we present the cross-tabulation of prior living arrangements and current living arrangements. About 66 percent of the first-time care community residents received regular assistance before they moved into the current community. While overall 32 percent of these first-time residents moved to the IL portion of the IL/ALs and 33 percent moved to freestanding ALs, the pattern differs by prior living arrangements: respondents who lived with extended

\footnotetext{
${ }^{2}$ We present the percentages and the item non-response in all of the tables. Appendix Tables 1 and 2 present the recalculated percentages of only the responders.

${ }^{3}$ Individuals were asked their previous city, state, and zip code, as well as their current zip code. We also matched survey respondents to the NIC Map database, which provides community characteristics, monthly charges, and zip code. We use NIC Map zip codes for those who match to the database, self-reported zip for everyone else. For respondents who did not report zip code but reported state and city, we use zip code of the central area for the calculation. The distance between the previous residence and the current community is computed using latitude and longitude coordinates from the center of the zip code and the Haversine formula.

${ }^{4}$ These international moves were not used to compute the distance due to lack of zip code coordinates outside the United States.
} 
family are more likely to move to freestanding ALs (49 percent) and much less likely to be in ILs. This pattern seems sensible, assuming that a certain level of care is achieved by living with family. A closer look at our sample also indicates that respondents who lived alone are less likely to rate their health as poor or fair compared to those who lived with extended family/friends or care givers (29 percent vs. 36 percent), suggesting that informal care provided by extended family may delay entry. Furthermore, about 70 percent of those who received regular assistance before moving decided to move to ALs (49 percent to freestanding ALs and 19 percent to the AL portion of IL/ALs), while 62 percent of those who did not receive assistance before moving decided to move into ILs (21 percent to freestanding ILs and 42 percent to the IL portion of IL/ALs).

For residents who lived in another age-qualified community before, 38 percent moved to freestanding ALs, with another 33 percent moving to the IL portion of IL/ALs. When breaking down respondents by community type they lived in prior to the current community, a general pattern of moving to a community of higher level of care is observed. For instance, 42 percent of residents who lived in an active adult community before are currently living in the IL portion of IL/ALs with an additional 29 percent in freestanding ALs. Among those who lived in a rehabilitation center or nursing home before, 85 percent currently live in ALs.

\section{Recent Movers}

Among those who reported how long they have been in the current community, about 50 percent have moved into the community in the past 24 months and another 14 percent moved during the past six months. It is interesting to further explore the characteristics of these recent movers. Understanding recent movers makes it possible to identify the type of people who demand care communities or the different types of care communities, and the reasons impacting their decisions to move. Table 3 presents the demographic and socioeconomic information of recent movers.

Not surprisingly, recent movers are relatively younger with an average age of 85 years and a median age of 86 years, more likely to be male (35 to 29 percent), and more likely to be currently married (22 to 14 percent), compared to residents who lived in the current community for over six months. There are no significant differences in terms of race, education, total monthly income or net worth. Recent movers are more likely to say their health has declined 
recently, more likely to have moved from another community, and more likely to have received help prior to living in the current community. This pattern suggests that declining health and the demand for assistance may be one of the reasons for the new residents moving to these types of communities.

Interestingly, while income and asset totals do not seem to vary between recent movers and long-stayers, the sources of each do differ. Recent movers have higher Social Security benefits, on average, and are less likely to have income from rental property, bank accounts, or be covered by Medicaid. They are also more likely to own an automobile and a house - which may be a temporary effect of not yet having sold these items. They are much less likely to have a trust.

Table 4 examines the characteristics of new movers based on the type of community where they currently reside. First the age differences between residents who moved to the AL portion of IL/ALs and the other three communities are significant, with the former being relatively older (an average age of 87.5 years). Compared to earlier work, our sample of recent movers is again significantly older. ${ }^{5}$ We also find that recent movers to the freestanding ALs are much less likely to still be married as compared to the other community types. ${ }^{6}$ While about 33 percent of all recent movers had a college degree, the highest representation, 52 percent, is among recent movers to the IL portion of IL/ALs. ${ }^{7}$

While no statistically significant differences in self-rated health emerged between the new movers and long-time residents, differences were observed, however, between new residents based on their community type. Freestanding ALs had the lowest proportion of new residents who rated their health as excellent or very good (less than 20 percent).

Although differences in monthly income and net worth of new residents were not statistically significant compared to those who lived in the community longer, the differences among new residents across communities are substantial. New residents to freestanding ILs and ALs have lower income and lower net worth than new residents in combined properties.

\footnotetext{
${ }^{5}$ According to The Independent Living Report, the resident who moved to independent living in the past six months was an average of 81.7 years and a median age of 82.8 years. In our sample, the resident who moved to independent living in the past six months was an average of 85 years and a median age of 84.5 years.

${ }^{6}$ Our sample of recent movers to IL is much less likely to be married than the 35-percent marriage rate found in The Independent Living Report.

${ }^{7}$ Our numbers are slightly lower than those reported in The Independent Living Report.
} 
Finally, recent movers to different community types vary by where they moved from. Particularly, 41 percent of the new residents to the IL portion of IL/ALs reported living in another community before. This is statistically significant from the other three types of communities. The corresponding numbers for the freestanding ILs, freestanding ALs, and the AL portion of the IL/ALs are 22, 29 and 23 percent.

\section{Short-distance vs. Long-distance Movers}

Another interesting dimension of the mobility of these care-community residents is how far they moved when selecting their community. The rich information of the survey allows us to distinguish long-distance movers from short-distance movers and further explore the differences between these two groups (Table 5).

About 21 percent of the sample moved over 100 miles, which we use as the definition of a long-distance mover. There are no statistical differences between short- and long-distance movers on race, gender, marital status, or total monthly income. Long-distance movers are relatively older, better educated, and in better health - both in terms of self-rated health and likelihood of receiving assistance before moving into the community.

The combined IL/ALs communities are more likely to be destinations for the longdistance movers compared to freestanding ILs or ALs. Interestingly, long-distance movers are both more likely to have lived in another age-qualified community before and have stayed in the current community longer, on average. Given the health and education results, this is likely reflecting a survivor bias - that long-distance movers live longer than short-distance movers. While long-distance movers are less likely to have Medicaid, they are more likely to move from a state that has less generous Medicaid eligibility rules.

On average, long-distance movers pay more for their residence and services. They also have relatively higher total expenses including other services they receive. Despite this and virtually no difference in total monthly income, long-distance movers are more likely to report that all of their expenses are covered by their current income (40 to 34 percent) and are more likely to have no concern about their ability to afford the fees of the community (34 to 28 percent), compared to short-distance movers.

While the income distribution does not vary between long- and short-distance movers, the sources of income differ. Long-distance movers are more likely to have income from stocks 
or bonds, and less likely to have rental income, a reverse mortgage, a veteran's pension, or income from government assistance, including SSI, Medicaid, and the HUD rental assistance program. Long-distance movers are relatively wealthier, being less likely to have total net worth less than \$100,000 (31 to 39 percent). They also are more likely to hold a brokerage, stock or mutual fund account and to hold a trust, but much less likely to own a house. In addition, the probability of giving a monetary gift is higher among long-distance movers (19 to 13 percent).

To further explore the characteristics of long-distance movers, we conducted regression analysis. $^{8}$ The results are presented in Table 6. We find that having children is positively correlated with being a long-distance mover, perhaps a signal of a motivating factor for the new location. African-Americans in our sample do not move as far as Caucasians. Medicaid recipients are less likely to be long-distance movers, as are those who own a house. Individuals who lived in another age-qualified care-community before are more likely to move far away. Not surprisingly, higher net worth is correlated with higher probability of being a long-distance mover. Interestingly, previously living in a state with less generous asset and income tests for Medicaid eligibility makes one more likely to be a long-distance mover.

\section{Future Living Arrangements}

We then examined the relationship between respondents' current living arrangement and their plan to move out (Table 7). About 10 percent of respondents indicated that they will move out of their community within the next 12 months. While residents of different types of communities are not significantly different in their likelihood of moving out, they differ in where they plan to move. Residents of freestanding ILs are more likely to want to move to a community that provides a higher level of care, such as to a community that offers assisted living services or nursing care (35 percent), while residents of the IL portion of IL/ALs are more likely to move to another community similar to the one in which they are living currently (48 percent). We also found that 28 percent of residents in freestanding ALs and 20 percent in the AL portion of IL/ALs are planning to move to communities that offer nursing care. In addition, about 25 to

\footnotetext{
${ }^{8}$ We estimated a probit model. Marginal effects are presented in Table 6. The explanatory variables include age, gender, race, education, marital status, indicators for health status, indicator of having children, measure of length being in the current community, total current income, total net worth, housing ownership, whether receive Medicaid, indicators of whether current state of residence has strict asset eligibility rules for Medicaid, whether previous state of residence has strict asset eligibility rules for Medicaid, indicators for current living arrangements, and controls for state of residence.
} 
35 percent of residents are planning to move to non-care-communities, such as to their own home, a home of a family member, or an apartment that does not include any services in the monthly fee.

Finally, we explored the stated reasons for wanting to move out. The financial reason is the predominant reason for wanting to move out, with over 50 percent of respondents who plan to move out in the next 12 months mentioning they "Can't afford it” or "Costs too high.” About 18 percent stated that health is the primary reason for them to move, either getting better or worse. Family concerns, such as the desire to be near a family member, are listed as the primary reason by 7 percent of residents. Another 15 percent mentioned that they are not satisfied with the services, including the quality of food and services.

There are apparent differences across communities in terms of reasons to move out. Residents of ALs are much more likely to move out for financial reasons (59 percent for freestanding ALs and 63 percent for the AL portion of IL/ALs), while other reasons, such as health or being unsatisfied with services, are more prevalent among IL residents (34 percent of residents in freestanding ILs mentioned health reasons and another 16 percent reported being unhappy with the services). Further investigation on the relationship between reasons to move and where to move shows that respondents who indicated financial concerns as the primary reason to move are more likely to move to another community similar to the one they are living in currently, while those planning to move for health reasons are more likely to move to communities offering assisted living services or nursing care.

The reasons individuals would like to move also varies significantly by the distance one moved originally (Table 8). Twenty-one percent of short-distance movers mentioned that health is the primary reason to move, while it is the reason for only 4 percent of the long-distance movers. In contrast, about 20 percent of long-distance movers stated that unsatisfactory service is the primary reason for a future move, compared to only 13 percent of short-distance movers. This finding is interesting because on the one hand, one might assume that long-distance movers may spend more time on their search. Thus the quality of match should be higher. On the other hand, those who moved a long way may have higher expectations for the service; consequently, they are more likely to be unhappy given a standard level of service. In terms of where to move, 53 percent of long-distance movers are most likely to move to an apartment that does not include any services in the monthly fee or to another community similar to the current one, and the 
corresponding number for short-distance movers is 14 percentage points lower. In addition, over 22 percent of short-distance movers plan to move to a community that offers nursing care, while the corresponding number for long-distance movers is only 13 percent.

The evolution of living arrangements shows that there are strong correlations among respondents' current living arrangements, previous living arrangements, and their plan to move in the future. The underlying need for care seems to be one of the reasons that impact the decision to move, and the reasons for moving out also predict where people want to move. We further investigate factors that relate respondents' desire to move out in the next 12 months using regression analysis. ${ }^{9}$ The regression results are summarized in Table 9. Respondents who are older, college educated, own their home, rate themselves in excellent or very good health, and experienced a decline in health in the past two years are more likely to want to move out within the next 12 months. On the other hand, those who are wealthier or who are Medicaid recipients are less likely to move out soon. We find that compared to those who have no concern, respondents that have some or considerable concerns about their ability to pay are significantly more likely to move out in the near future.

\section{Conclusions}

There is substantial geographic mobility among the respondents. Between 15 and 20 percent moved across state lines, and the average person moved between 150 and 175 miles away from their previous residence, which was typically an arrangement where they lived alone or only with their spouse. Many were getting assistance before they moved to their current community, either from family or another type of care community. For those moving between communities, there tends to be a pattern of moving towards more services. Interestingly, new residents in freestanding ILs and freestanding ALs have lower income and lower net worth than new residents in combined IL/AL properties.

Combined IL/AL properties seem to attract residents from longer distances than freestanding properties. These long-distance movers seem to be different from individuals who

\footnotetext{
${ }^{9}$ We estimated a probit model. The explanatory variables included basic demographics, such as age, age squared, and indicator for gender, married, race, college education, having kids, having lived in another community before, and whether moved over 100 miles. We also controlled for variables related to health, including indicator for selfrated health condition as excellent or good health, self-rated health condition compared to two years ago as much better, somewhat better, or about the same health, and indicators for receiving regular care before moving in. Income, net worth and indicator variables for home ownership and Medicaid are included in the analysis. Moreover, indicators for current living arrangement are controlled for.
} 
only move a short distance (less than 100 miles). Long-distance movers tend to be in better health, wealthier, and more educated. While their incomes are comparable, they pay more for their services and are less concerned about their ability to continue paying these bills. Interestingly, long-distance movers are more likely to come from states with stricter Medicaid eligibility rules.

Finally, we explored future plans to move. About 10 percent of the sample plans to move out within the next year; moving to places with more services, fewer services, and the same level of services are all roughly equally likely. Finances are the most important reason stated, followed by health and dissatisfaction with current services. 


\section{References}

Anderson, Kate, Eric French, and Tina Lam. 2004. "You Can’t Take It With You: Asset RunDown at the End of the Life Cycle.” Economic Perspectives 3: 40-54.

Assisted Living Federation of America (ALFA). 1998. The Assisted Living Industry: An Overview - 1998. Fairfax, VA: Price Waterhouse and ALFA.

Coe, Norma B. and April Yanyuan Wu. 2012. "Residents in Seniors Housing and Care Communities: Overview of the Residents Financial Survey.” Working Paper 2012-6. Chestnut Hill, MA: Center for Retirement Research at Boston College.

Fisher, Jonathan D., David S. Johnson, Joseph T. Marchand, Timothy M. Smeeding, and Barbara Boyle Torrey. 2007. "No Place like Home: Older Adults and Their Housing.” Journal of Gerontology 62B(2): S120-S128.

Haverstick, Kelly and Natalia A. Zhivan. 2009. "Older American on the go: How Often, Where and Why?” Issue in Brief 9-18. Chestnut Hill, MA: Center for Retirement Research at Boston College.

National Investment Center for the Seniors Housing \& Care Industry (NIC). 1998. "National Survey of Assisted Living Residents: Who is the Customer?” Annapolis, MD.

“The Independent Living Report.” 2009. Washington, DC: American Seniors Housing Association.

Venti, Steven F. and David A. Wise. 2002. “Aging and Housing Equity.” In Innovations in Retirement Financing, edited by Olivia. S. Mitchell, Zvi Bodie, P. Brett Hammond, and Stephen Zeldes, 254-281. Philadelphia, PA: University of Pennsylvania Press.

Venti, Steven F. and David A. Wise. 2004. “Aging and Housing Equity: Another Look.” In Perspectives on the Economics of Aging, edited by David A. Wise, 127-175. Chicago, IL: University of Chicago Press. 
Table 1. Prior Living Arrangements, by Community Type

\begin{tabular}{|c|c|c|c|c|}
\hline & $\begin{array}{c}\text { Freestanding } \\
\text { IL } \\
\end{array}$ & Combined IL & $\begin{array}{c}\text { Freestanding } \\
\text { AL }\end{array}$ & Combined AL \\
\hline \multicolumn{5}{|l|}{ Prior living arrangement* } \\
\hline Living by themselves or only with spouse & $85.1 \%$ & $89.7 \%$ & $81.1 \%$ & $85.0 \%$ \\
\hline Living with extended family, friends, or caregiver & 11.1 & 7.6 & 17.2 & 12.3 \\
\hline Non-response & 3.8 & 2.7 & 1.7 & 2.7 \\
\hline Living in another community & 19.0 & 27.0 & 29.0 & 28.0 \\
\hline In active adult community & 50.0 & 56.3 & 34.7 & 40.8 \\
\hline In ILs & 34.1 & 39.0 & 30.0 & 33.0 \\
\hline In ALs & 13.6 & 3.8 & 28.2 & 22.3 \\
\hline In rehabilitation center or nursing home & 2.3 & 0.9 & 7.3 & 3.9 \\
\hline Non-response & 4.2 & 3.0 & 1.8 & 2.5 \\
\hline \multicolumn{5}{|l|}{ Health* } \\
\hline Received assistance before moving in & 31.9 & 14.8 & 54.3 & 42.4 \\
\hline Non-response & 4.6 & 3.4 & 2.4 & 2.7 \\
\hline \multicolumn{5}{|l|}{ Distance moved, over state boundary } \\
\hline Crossed state boundary & $14.26 \%$ & $16.7 \%$ & $18.0 \%$ & $20.4 \%$ \\
\hline Within-state move & 80.3 & 79.4 & 79.2 & 76.9 \\
\hline Non-response/not computable & 5.5 & 3.9 & 2.8 & 2.7 \\
\hline \multicolumn{5}{|l|}{ Distance moved (miles) } \\
\hline Average distance & 165.0 & 183.6 & 168.7 & 189.9 \\
\hline Median distance & 6.7 & 8.2 & 7.4 & 8.5 \\
\hline Non-response/not computable & $6.5 \%$ & $5.0 \%$ & $3.9 \%$ & $3.4 \%$ \\
\hline \multicolumn{5}{|l|}{ Months in the current community } \\
\hline Average months & 43.8 & 36.4 & 37.7 & 35.6 \\
\hline Median months & 25.0 & 25.0 & 22.0 & 25.0 \\
\hline Questionable & $1.0 \%$ & $2.1 \%$ & $1.3 \%$ & $1.7 \%$ \\
\hline Non-response & $7.8 \%$ & $8.8 \%$ & $7.8 \%$ & $7.4 \%$ \\
\hline Observations & 477 & 854 & 880 & 406 \\
\hline
\end{tabular}

Source: Authors' calculations of the Residents' Financial Survey.

*: See Appendix Table 1 for calculations of the percentages that treat non-response as missing observations. 


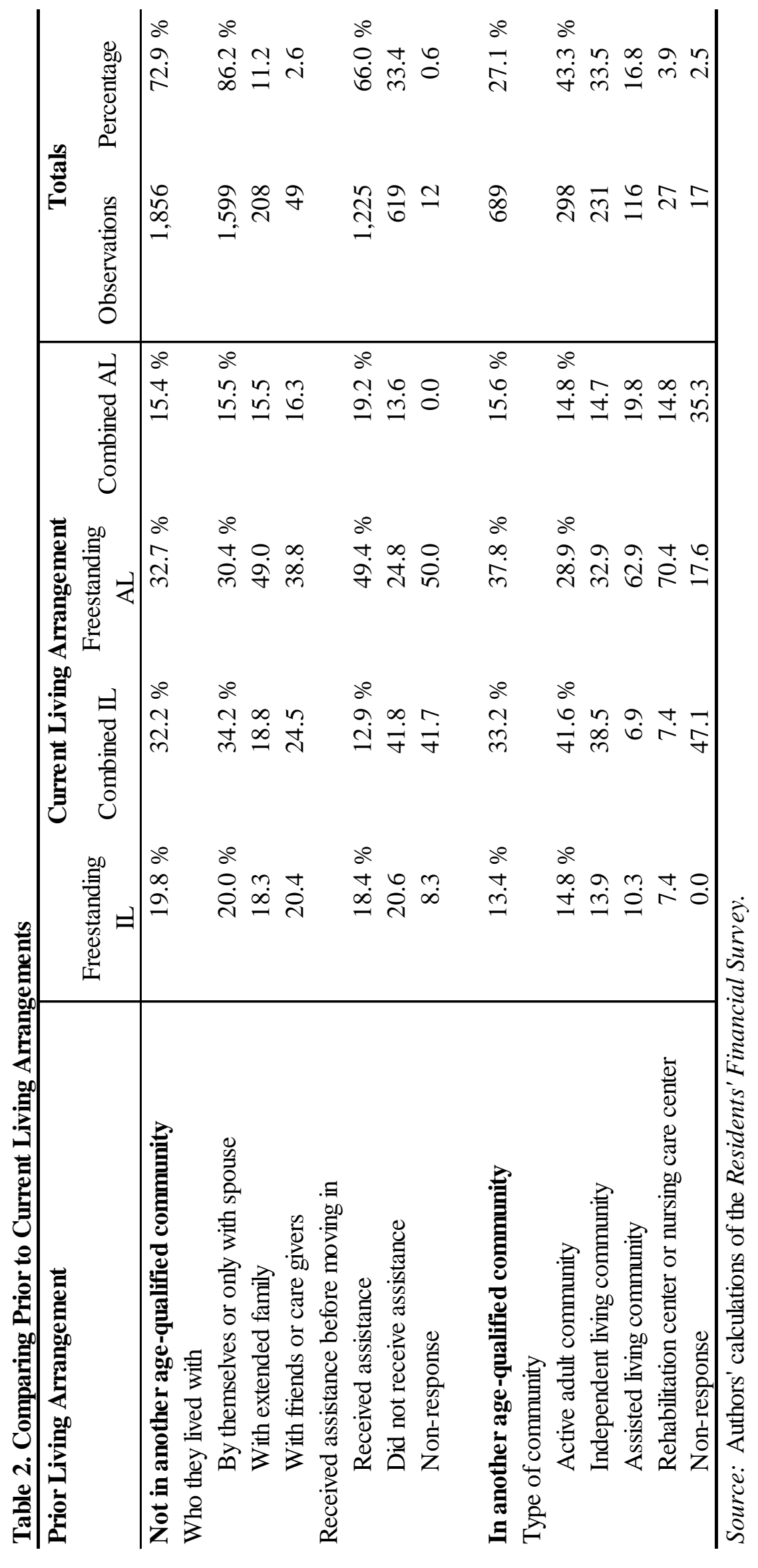


Table 3. Comparing Characteristics of Recent Movers to Those Stayed Longer

\begin{tabular}{|c|c|c|c|}
\hline Age & Recent movers & \multicolumn{2}{|c|}{$\begin{array}{l}\text { Residents who stayed } \\
\text { longer than six months }\end{array}$} \\
\hline Average age & 84.9 & 86.7 & $* * *$ \\
\hline Non-response & 2.0 & 2.9 & \\
\hline \multicolumn{4}{|l|}{ Gender* } \\
\hline Male & $35.1 \%$ & $29.4 \%$ & $* *$ \\
\hline Non-response & 2.0 & 2.9 & \\
\hline \multicolumn{4}{|l|}{ Race* } \\
\hline White & $97.7 \%$ & $97.3 \%$ & \\
\hline Non-response & 2.0 & 2.5 & \\
\hline \multicolumn{4}{|l|}{ Marital status* } \\
\hline Married & $21.7 \%$ & $13.8 \%$ & $* * *$ \\
\hline Non-response & 1.4 & 2.3 & \\
\hline \multicolumn{4}{|l|}{ Education* } \\
\hline College educated & $33.3 \%$ & $30.2 \%$ & \\
\hline Non-response & 2.0 & 2.7 & \\
\hline \multicolumn{4}{|l|}{ Health* } \\
\hline Self rated excellent or very good & $33.2 \%$ & $30.8 \%$ & \\
\hline Non-response & 1.7 & 2.3 & \\
\hline Same/better compared to two years ago & 46.7 & 52.2 & * \\
\hline Non-response & 1.7 & 2.5 & \\
\hline Received assistance before moving in & 45.5 & 35.4 & $* * *$ \\
\hline Non-response & 2.3 & 3.2 & \\
\hline \multicolumn{4}{|l|}{ Prior living arrangement* } \\
\hline Living in another community & $31.0 \%$ & $25.7 \%$ & $* *$ \\
\hline Non-response & 2.0 & 3.8 & \\
\hline \multicolumn{4}{|l|}{ Distance moved (mile) } \\
\hline Average distance & 149.6 & 171.5 & \\
\hline Non-response/not computable & 3.1 & 3.7 & \\
\hline \multicolumn{4}{|l|}{ Income by source } \\
\hline Social Security & $98.5 \%$ & $97.4 \%$ & \\
\hline Average Social Security benefits & $\$ 1,351$ & $\$ 1,276$ & $* *$ \\
\hline Pension/annuity & 65.1 & 64.6 & \\
\hline Average pension income & $\$ 1,632$ & $\$ 1,705$ & \\
\hline Interest from bank accounts & 43.8 & 50.7 & $* *$ \\
\hline Interest from stocks/bonds & 43.2 & 45.2 & \\
\hline Rental income & 4.4 & 7.8 & $* *$ \\
\hline Business or farm & 2.4 & 2.1 & \\
\hline Trust fund & 3.8 & 5.5 & \\
\hline Reverse mortgage & 0.1 & 0.0 & \\
\hline Medicaid & 3.5 & 5.7 & * \\
\hline SSI & 1.7 & 1.2 & \\
\hline Food Stamps & 0.0 & 0.0 & \\
\hline HUD rental assistance & 0.0 & 0.0 & \\
\hline Other means-tested sources & 0.0 & 0.0 & \\
\hline \multicolumn{4}{|l|}{ Asset types } \\
\hline LTC insurance & $15.3 \%$ & $15.5 \%$ & \\
\hline Checking/savings & 87.4 & 87.8 & \\
\hline Brokerage/stocks/bonds & 45.6 & 45.2 & \\
\hline 401(k), IRA & 23.7 & 20.8 & \\
\hline Trust & 8.5 & 12.8 & $* *$ \\
\hline House, property, land & 33.0 & 19.3 & $* * *$ \\
\hline Farm, business & 1.1 & 2.1 & \\
\hline Automobile & 39.2 & 24.0 & $* * *$ \\
\hline Observations & 355 & 2,023 & \\
\hline
\end{tabular}

* significant at $10 \%, * *$ significant at $5 \%, * * *$ significant at $1 \%$.

Source: Authors' calculations of the Residents' Financial Survey.

*: See Appendix Table 2 for calculations of the percentages that treat non-response as missing observations. 
Table 4. Characteristics of New Movers, by Community Type

\begin{tabular}{|c|c|c|c|c|}
\hline & $\begin{array}{c}\text { Freestanding } \\
\text { IL }\end{array}$ & Combined IL & $\begin{array}{c}\text { Freestanding } \\
\text { AL }\end{array}$ & Combined AL \\
\hline \multicolumn{5}{|l|}{ Age } \\
\hline Average age & 84.1 & 84.6 & 84.6 & 87.5 \\
\hline Non-response & $6.3 \%$ & $6.1 \%$ & $0.8 \%$ & $7.5 \%$ \\
\hline \multicolumn{5}{|l|}{ Gender* } \\
\hline Male & $38.7 \%$ & $41.4 \%$ & $30.9 \%$ & $26.9 \%$ \\
\hline Non-response & 1.2 & 3.5 & 0.8 & 1.9 \\
\hline \multicolumn{5}{|l|}{ Marital status* } \\
\hline Married & $17.7 \%$ & $33.0 \%$ & $12.9 \%$ & $23.1 \%$ \\
\hline Non-response & 1.6 & 2.6 & 0.0 & 1.9 \\
\hline \multicolumn{5}{|l|}{ Education* } \\
\hline College educated & $27.4 \%$ & $51.8 \%$ & $22.6 \%$ & $26.9 \%$ \\
\hline Non-response & 1.6 & 4.3 & 0.0 & 1.9 \\
\hline \multicolumn{5}{|l|}{ Health* } \\
\hline Self rated excellent or very good & $32.3 \%$ & $48.7 \%$ & $19.4 \%$ & $34.6 \%$ \\
\hline Non-response & 1.6 & 3.5 & 0.0 & 1.9 \\
\hline Same/better compared to two years ago & 45.2 & 53.2 & 36.3 & 59.6 \\
\hline Non-response & 1.6 & 3.5 & 0.8 & 1.9 \\
\hline Received assistance before moving in & 40.3 & 21.6 & 71.3 & 42.3 \\
\hline Non-response & 1.6 & 3.5 & 1.6 & 1.9 \\
\hline \multicolumn{5}{|l|}{ Prior Living arrangement* } \\
\hline Living in another community & $22.0 \%$ & $41.4 \%$ & $29.0 \%$ & $23.1 \%$ \\
\hline Non-response & 0.0 & 3.5 & 0.0 & 1.9 \\
\hline \multicolumn{5}{|l|}{ Distance moved (mile) } \\
\hline Average distance & 136.5 & 168.2 & 139.7 & 148.7 \\
\hline Median distance & 6.2 & 9.8 & 7.2 & 6.4 \\
\hline Non-response/not computable & $1.6 \%$ & $3.5 \%$ & $3.2 \%$ & $5.7 \%$ \\
\hline \multicolumn{5}{|l|}{ Monthly income amount* } \\
\hline$<\$ 850$ & $0 \%$ & $0 \%$ & $4.8 \%$ & $0 \%$ \\
\hline$\$ 850-\$ 1,200$ & 3.2 & 2.6 & 10.5 & 5.7 \\
\hline$\$ 1,200-\$ 1,500$ & 11.1 & 5.2 & 11.3 & 5.7 \\
\hline$\$ 1,500-\$ 2,000$ & 19.1 & 9.6 & 15.3 & 15.1 \\
\hline$\$ 2,000-\$ 2,500$ & 15.9 & 11.3 & 11.3 & 7.6 \\
\hline$\$ 2,500-\$ 3,000$ & 17.5 & 10.4 & 10.5 & 7.6 \\
\hline$\$ 3,000-\$ 3,500$ & 11.1 & 16.5 & 16.1 & 13.2 \\
\hline$\$ 3,500+$ & 19.1 & 35.7 & 17.7 & 35.9 \\
\hline Questionable & 0.0 & 1.7 & 0 & 0 \\
\hline Non-response & 3.2 & 7.0 & 2.4 & 9.4 \\
\hline \multicolumn{5}{|l|}{ Income by source } \\
\hline Social Security & $98.4 \%$ & $98.2 \%$ & $98.3 \%$ & $100.0 \%$ \\
\hline Pension/annuity & 67.7 & 67.0 & 63.6 & 61.2 \\
\hline Interest from bank accounts & 40.3 & 56.9 & 39.2 & 30.6 \\
\hline Interest from stocks/bonds & 35.5 & 61.5 & 30.0 & 44.9 \\
\hline Rental income & 3.2 & 4.6 & 4.2 & 6.1 \\
\hline Business or farm & 3.2 & 4.6 & 0.0 & 2.0 \\
\hline Trust fund & 4.8 & 2.8 & 4.2 & 4.1 \\
\hline Reverse mortgage & 0.0 & 1.8 & 0.0 & 0.0 \\
\hline Medicaid & 8.1 & 10.1 & 14.9 & 11.8 \\
\hline SSI & 0.0 & 0.0 & 6.6 & 7.8 \\
\hline Food Stamps & 1.6 & 0.0 & 3.3 & 2.0 \\
\hline Other means-tested sources & 1.6 & 0.0 & 0.0 & 0.0 \\
\hline \multicolumn{5}{|l|}{ Total net worth (in thousands)* } \\
\hline$<\$ 50$ & $31.8 \%$ & $14.8 \%$ & $31.5 \%$ & $26.4 \%$ \\
\hline$\$ 50-\$ 100$ & 12.7 & 13.9 & 10.5 & 9.4 \\
\hline$\$ 100-\$ 300$ & 20.6 & 17.4 & 25.0 & 17.0 \\
\hline$\$ 300-\$ 500$ & 12.7 & 15.7 & 8.9 & 1.9 \\
\hline$\$ 500-\$ 750$ & 6.4 & 8.7 & 5.7 & 18.9 \\
\hline$\$ 750-\$ 1,000$ & 6.4 & 9.6 & 4.0 & 9.4 \\
\hline$\$ 1,000-\$ 2,000$ & 1.6 & 6.1 & 2.4 & 0.0 \\
\hline$\$ 2,000+$ & 1.6 & 5.2 & 1.6 & 5.7 \\
\hline Non-response & 6.4 & 8.7 & 10.5 & 11.3 \\
\hline \multicolumn{5}{|l|}{ Asset types } \\
\hline LTC insurance & $9.8 \%$ & $16.2 \%$ & $16.1 \%$ & $19.9 \%$ \\
\hline Checking/savings & 87.1 & 90.0 & 88.3 & 80.0 \\
\hline Brokerage/stocks/bonds & 33.9 & 63.6 & 31.7 & 54.0 \\
\hline 401(k), IRA & 19.4 & 27.3 & 24.2 & 20.0 \\
\hline Trust & 9.7 & 9.1 & 6.7 & 10.0 \\
\hline House, property, land & 35.5 & 31.8 & 35.0 & 28.0 \\
\hline Farm, business & 1.6 & 2.7 & 0.0 & 0.0 \\
\hline Automobile & 45.2 & 60.9 & 25.0 & 18.0 \\
\hline Observations & 63 & 115 & 124 & 53 \\
\hline
\end{tabular}

Source: Authors' calculations of the Residents' Financial Survey.

*: See Appendix Table 1 for calculations of the percentages that treat non-response as missing observations. 
Table 5. Comparing Characteristics of Long-distance to Short-distance Movers

\begin{tabular}{|c|c|c|c|c|c|}
\hline Age & \multicolumn{2}{|c|}{$\begin{array}{c}\text { Long-distance } \\
\text { Movers }\end{array}$} & \multicolumn{3}{|c|}{$\begin{array}{c}\text { Short-distance } \\
\text { Movers }\end{array}$} \\
\hline Average age & & 87.0 & & 86.2 & $* *$ \\
\hline Non-response & & 2.3 & & 2.7 & \\
\hline \multicolumn{6}{|l|}{ Education* } \\
\hline College educated & & $35.2 \%$ & & $30.7 \%$ & $* *$ \\
\hline Non-response & & 0.4 & & 0.7 & \\
\hline \multicolumn{6}{|l|}{ Health* } \\
\hline Self rated excellent or very good & & $36.5 \%$ & & $30.9 \%$ & $* *$ \\
\hline Non-response & & 0.2 & & 0.3 & \\
\hline Received assistance before moving in & & 30.0 & & 38.5 & $* * *$ \\
\hline Non-response & & 0.8 & & 1.1 & \\
\hline \multicolumn{6}{|l|}{ Prior Living arrangement* } \\
\hline Living in another community & & $33.6 \%$ & & $24.8 \%$ & ** \\
\hline Non-response & & 1.1 & & 1.7 & \\
\hline \multicolumn{6}{|l|}{ Months in the current community } \\
\hline Average months & & 42.6 & & 34.4 & $* * *$ \\
\hline Non-response & & 9.4 & & 7.8 & \\
\hline \multicolumn{6}{|l|}{ Expenses covered by current income* } \\
\hline All of the expenses & & $40.1 \%$ & & $33.6 \%$ & $* * *$ \\
\hline Most of the expenses & & 22.9 & & 27.9 & $* *$ \\
\hline Some of the expenses & & 25.4 & & 28.0 & \\
\hline None of the expenses & & 5.7 & & 4.9 & \\
\hline Non-response & & 5.9 & & 5.6 & \\
\hline \multicolumn{6}{|l|}{ Relative to my ability to afford the fees* } \\
\hline No concern & & $33.8 \%$ & & $27.5 \%$ & $* * *$ \\
\hline Some concern & & 38.7 & & 44.4 & $* *$ \\
\hline Considerable concern & & 22.9 & & 22.4 & \\
\hline Non-response & & 4.6 & & 5.8 & \\
\hline \multicolumn{6}{|l|}{ Monthly bill per person } \\
\hline Average & & $3,312.7$ & & 3,128.9 & $* *$ \\
\hline Non-response & & 9.2 & & 10.5 & \\
\hline \multicolumn{6}{|l|}{ Income by Source } \\
\hline Social Security & & $97.2 \%$ & & $97.8 \%$ & \\
\hline Average Social Security benefits & $\$$ & 1,308 & $\$$ & 1,282 & \\
\hline Pension/annuity & & 65.8 & & 63.1 & \\
\hline Average pension income & $\$$ & 1,820 & $\$$ & 1,645 & \\
\hline Interest from bank accounts & & 50.3 & & 48.5 & \\
\hline Interest from stocks/bonds & & 50.9 & & 43.0 & $* * *$ \\
\hline Rental income & & 4.6 & & 7.9 & $* *$ \\
\hline Business or farm & & 2.4 & & 1.8 & \\
\hline Trust fund & & 6.8 & & 5.1 & \\
\hline Medicaid & & 3.8 & & 5.9 & $*$ \\
\hline SSI & & 0.1 & & 1.6 & * \\
\hline Food Stamps & & 0.0 & & 0.1 & \\
\hline HUD rental assistance & & 0.0 & & 0.1 & * \\
\hline \multicolumn{6}{|l|}{ Total net worth (in thousands)* } \\
\hline$<\$ 50$ & & $22.1 \%$ & & $26.4 \%$ & $* *$ \\
\hline$\$ 50-\$ 100$ & & 9.2 & & 12.1 & $*$ \\
\hline$\$ 100-\$ 300$ & & 17.0 & & 17.7 & \\
\hline$\$ 300-\$ 500$ & & 12.0 & & 9.9 & \\
\hline$\$ 500-\$ 750$ & & 9.0 & & 7.5 & \\
\hline$\$ 750-\$ 1,000$ & & 5.7 & & 6.0 & \\
\hline$\$ 1,000-\$ 2,000$ & & 7.1 & & 4.8 & $* *$ \\
\hline$\$ 2,000+$ & & 5.5 & & 2.5 & $* * *$ \\
\hline Non-response & & 12.4 & & 13.0 & \\
\hline Asset types & & & & & \\
\hline LTC insurance & & $17.3 \%$ & & $14.9 \%$ & \\
\hline Checking/savings & & 87.1 & & 87.5 & \\
\hline Brokerage/stocks/bonds & & 52.5 & & 43.4 & $* * *$ \\
\hline 401(k), IRA & & 22.3 & & 21.0 & \\
\hline Trust & & 14.5 & & 11.5 & $*$ \\
\hline House, property, land & & 22.9 & & 15.1 & $* * *$ \\
\hline Farm, business & & 2.0 & & 1.9 & \\
\hline Automobile & & 25.6 & & 25.9 & \\
\hline Gifts given in the last five years & & & & & \\
\hline Yes & & $19.2 \%$ & & $13.4 \%$ & \\
\hline Non-response & & 5.7 & & $3.7 \%$ & \\
\hline Observations & & 524 & & 1,971 & \\
\hline
\end{tabular}


Table 6. Probability of Being a Long-distance Mover

\begin{tabular}{|c|c|c|}
\hline & $\begin{array}{c}\text { Marginal } \\
\text { Effect }\end{array}$ & $\begin{array}{c}\text { Standard } \\
\text { Error }\end{array}$ \\
\hline Years in current community & $0.009 * * *$ & 0.003 \\
\hline Age & 0.023 & 0.015 \\
\hline Age squared (in hundreds) & -0.013 & 0.009 \\
\hline Female & -0.001 & 0.020 \\
\hline College educated & 0.020 & 0.020 \\
\hline Currently married & -0.009 & 0.025 \\
\hline Excellent/very good health (self-rated) & 0.032 & 0.020 \\
\hline Same/somewhat better/much better (compared to two years ago) & 0.009 & 0.018 \\
\hline Black & $-0.110 * *$ & 0.052 \\
\hline Have children & $0.057 * *$ & 0.025 \\
\hline Lived in another age-qualified community before & $0.076 * * *$ & 0.021 \\
\hline Received regular assistance prior to moving into community & -0.030 & 0.019 \\
\hline \multicolumn{3}{|l|}{ Monthly income amount } \\
\hline$\$ 850-\$ 1,200$ & 0.062 & 0.070 \\
\hline$\$ 1,200-\$ 1,500$ & 0.109 & 0.073 \\
\hline$\$ 1,500-\$ 2,000$ & 0.046 & 0.064 \\
\hline$\$ 2,000-\$ 2,500$ & 0.066 & 0.066 \\
\hline$\$ 2,500-\$ 3,000$ & 0.113 & 0.071 \\
\hline$\$ 3,000-\$ 3,500$ & 0.011 & 0.061 \\
\hline$\$ 3,500+$ & 0.044 & 0.059 \\
\hline \multicolumn{3}{|l|}{ Total net worth (in thousands) } \\
\hline$\$ 50-\$ 100$ & -0.028 & 0.029 \\
\hline$\$ 100-\$ 300$ & 0.016 & 0.028 \\
\hline$\$ 300-\$ 500$ & $0.061 *$ & 0.036 \\
\hline$\$ 500-\$ 750$ & 0.064 & 0.042 \\
\hline$\$ 750-\$ 1,000$ & 0.014 & 0.042 \\
\hline$\$ 1,000-\$ 2,000$ & $0.099 * *$ & 0.050 \\
\hline$\$ 2,000+$ & $0.202 * * *$ & 0.066 \\
\hline Own a house & $-0.073 * * *$ & 0.020 \\
\hline Medicaid recipient & $-0.061 *$ & 0.036 \\
\hline Current state of residence has strict asset eligibility rules for Medicaid & 0.133 & 0.222 \\
\hline Previous state of residence has strict asset eligibility rules for Medicaid & $0.077 * *$ & 0.033 \\
\hline In IL portion of IL/ALs & -0.049 & 0.036 \\
\hline In freestanding $\mathrm{AL}$ & -0.040 & 0.035 \\
\hline In AL portion of IL/ALs & 0.023 & 0.043 \\
\hline State Indicators & Yes & \\
\hline Observations & 2,413 & \\
\hline
\end{tabular}

Note : We included indicator variables for non-response for each of explanatory variables.

* significant at $10 \%$, ** significant at $5 \%$, *** significant at $1 \%$.

Source: Authors' calculations of the Residents' Financial Survey. 


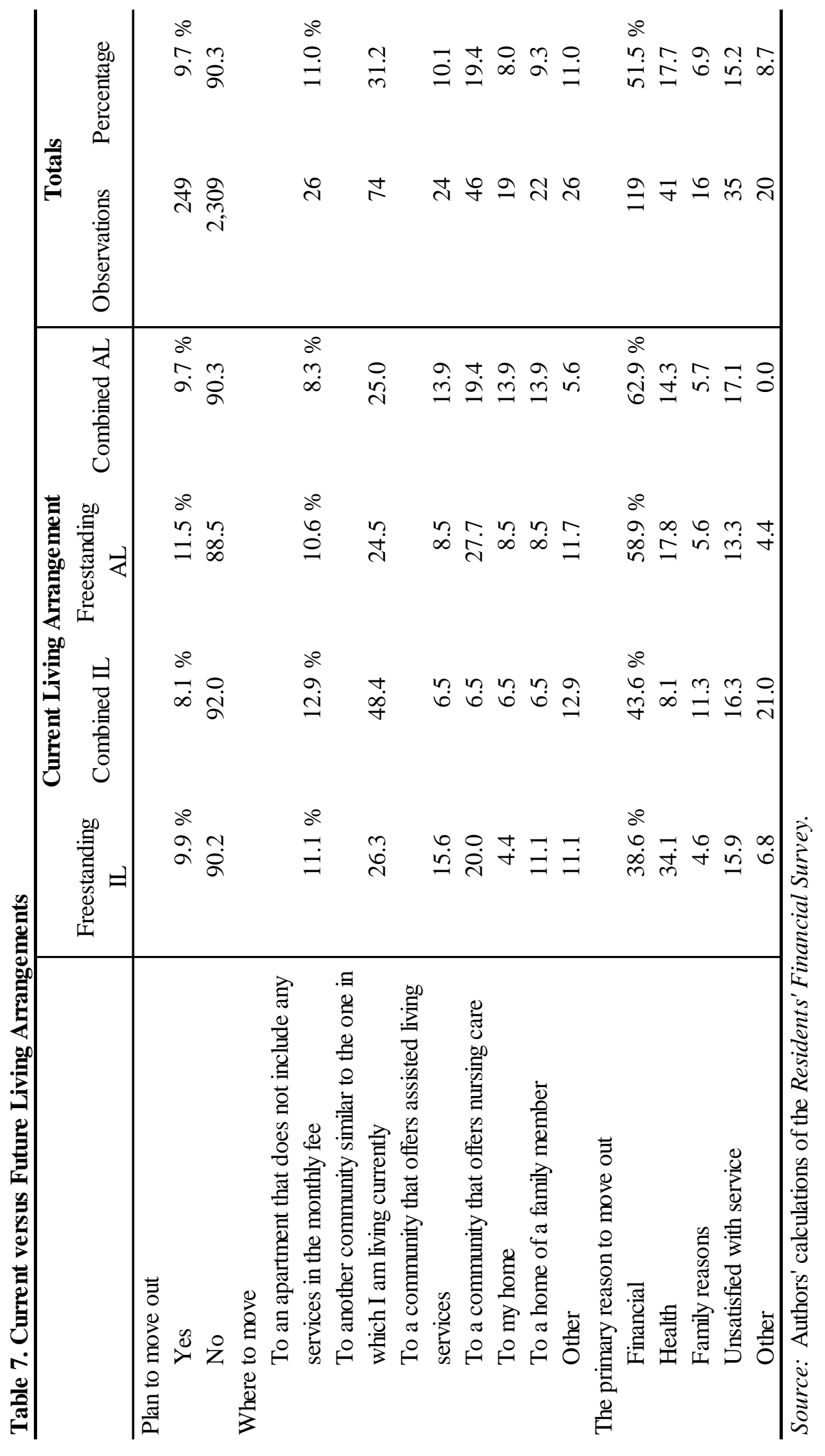


Table 8. Future living arrangements: Comparing Long-distance Movers to Short-distance Movers

\begin{tabular}{lcc}
\hline & $\begin{array}{c}\text { Long-distance } \\
\text { Movers }\end{array}$ & $\begin{array}{c}\text { Short-distance } \\
\text { Movers }\end{array}$ \\
\hline Plan to move out & $9.7 \%$ & $9.6 \%$ \\
Yes & 3.2 & 1.6 \\
$\quad$ Non-response & $54.4 \%$ & $51.2 \%$ \\
The primary reason to move out & 4.4 & 21.3 \\
$\quad$ Financial & 19.6 & 13.2 \\
Health & 8.7 & 6.6 \\
Unsatisfied with service & 13.0 & 7.5 \\
Family & & \\
Other & & \\
Where to move & $17.0 \%$ & $10.1 \%$ \\
To an apartment that does not include any services in the & & \\
monthly fee & 36.2 & 29.1 \\
To another community similar to the one in which I am living & 6.4 & 11.2 \\
currently & 12.8 & 22.4 \\
To a community that offers assisted living services & 4.3 & 7.8 \\
To a community that offers nursing care & 10.6 & 10.1 \\
To my home & 12.8 & 9.5 \\
To a home of a family member & 524 & 1,971 \\
Other & &
\end{tabular}

Source : Authors' calculations of the Residents' Financial Survey. 
Table 9. Probability of Moving Out Within the Next 12 Months

\begin{tabular}{|c|c|c|}
\hline & $\begin{array}{c}\text { Marginal } \\
\text { Effect }\end{array}$ & $\begin{array}{l}\text { Standard } \\
\text { Error }\end{array}$ \\
\hline Years in current community & -0.001 & 0.002 \\
\hline Age & $0.016 *$ & 0.008 \\
\hline Age squared (in hundreds) & $-0.011 * *$ & 0.005 \\
\hline Female & -0.003 & 0.012 \\
\hline College educated & $0.023 *$ & 0.013 \\
\hline Currently married & -0.002 & 0.016 \\
\hline Excellent/very good health (self-rated) & $0.023 *$ & 0.013 \\
\hline Same/somewhat better/much better (compared to two years ago) & $-0.019 *$ & 0.011 \\
\hline Black & 0.048 & 0.067 \\
\hline Have children & -0.017 & 0.018 \\
\hline Lived in another age-qualified community before & 0.006 & 0.012 \\
\hline \multicolumn{3}{|l|}{ Monthly income amount } \\
\hline$\$ 850-\$ 1,200$ & -0.030 & 0.025 \\
\hline$\$ 1,200-\$ 1,500$ & $-0.038 *$ & 0.022 \\
\hline$\$ 1,500-\$ 2,000$ & -0.028 & 0.025 \\
\hline$\$ 2,000-\$ 2,500$ & -0.012 & 0.029 \\
\hline$\$ 2,500-\$ 3,000$ & -0.017 & 0.028 \\
\hline$\$ 3,000-\$ 3,500$ & -0.015 & 0.029 \\
\hline$\$ 3,500+$ & -0.029 & 0.028 \\
\hline \multicolumn{3}{|l|}{ Total net worth (in thousands) } \\
\hline$\$ 50-\$ 100$ & 0.002 & 0.017 \\
\hline$\$ 100-\$ 300$ & $-0.031 * *$ & 0.013 \\
\hline$\$ 300-\$ 500$ & $-0.027 *$ & 0.016 \\
\hline$\$ 500-\$ 750$ & $-0.041 * * *$ & 0.015 \\
\hline$\$ 750-\$ 1,000$ & -0.022 & 0.021 \\
\hline$\$ 1,000-\$ 2,000$ & -0.010 & 0.026 \\
\hline$\$ 2,000+$ & $-0.042 *$ & 0.023 \\
\hline Own a house & $0.032 * *$ & 0.016 \\
\hline Medicaid recipient & -0.023 & 0.022 \\
\hline Moved over 100 miles to live in current residence & 0.007 & 0.013 \\
\hline Total monthly expenses for housing and care (log) & 0.016 & 0.012 \\
\hline Have no concern about ability to pay fees & $-0.107 * * *$ & 0.010 \\
\hline Have some concern about ability to pay fees & $-0.099 * * *$ & 0.011 \\
\hline In IL portion of IL/ALs & -0.007 & 0.015 \\
\hline In freestanding $\mathrm{AL}$ & -0.001 & 0.015 \\
\hline In AL portion of IL/ALs & -0.015 & 0.016 \\
\hline Observations & 2,510 & \\
\hline
\end{tabular}

Note : We included indicator variables for the non-response of each of explanatory variables

* significant at $10 \%,{ }^{* *}$ significant at $5 \%, * * *$ significant at $1 \%$.

Source: Authors' calculations of the Residents' Financial Survey. 
Freestanding

IL
$\mathrm{AL}$

Panel A: Entire Sample (Table 1)

Prior Living arrangement

Living by themselves or only with spouse

Living with extended family, friends, or

caregiver

Living in another community

Health

Received assistance before moving in

$\begin{array}{lcll}88.5 \% & 89.7 \% & 81.1 \% & 85.0 \% \\ 11.5 & 7.8 & 17.5 & 12.7 \\ 19.8 & 27.8 & 29.5 & 28.7 \\ & & & \\ 33.4 \% & 15.3 \% & 55.7 \% & 43.5 \%\end{array}$

Panel B: New Mover Sample (Table 4)

Gender

Male

Marital Status

Married

Education

College educated

Health

Self rated excellent or very good

Same/better compared to two years ago

Received assistance before moving in

Monthly Income

$<\$ 850$

$\$ 850-\$ 1,200$

$\$ 1,200-\$ 1,500$

$\$ 1,500-\$ 2,000$

$\$ 2,000-\$ 2,500$

$\$ 2,500-\$ 3,000$

$\$ 3,000-\$ 3,500$

$\$ 3,500+$

39.2

18.0

54.2

27.9

32.8

45.9

41.0

55.1

22.4

0.0

3.3

11.5

19.7

16.4

18.0

11.5

19.7

33.9

13.6

22.0

13.6

6.8

6.8

1.7

1.7

$\$ 2,000+$

\$750-\$1,000

$\$ 1,000-\$ 2,000$

1.7

Source: Authors' calculations of the Residents' Financial Survey.

Combined AL AL
27.4

23.5

27.4

35.3

60.8

43.1

$72.5 \quad 43.1$

5.0

0.0
10.7

11.6

15.7

11.6

10.7

16.5

18.2

35.1

11.7

27.9

9.9

6.3

4.5

2.7

1.8

6.2

6.2

16.7

8.3

8.3

14.6

39.6

29.8

10.6

19.1

2.1

21.3

10.6

$\begin{array}{lll}6.7 & 2.7 & 0.0\end{array}$

5.7

6.4 
Appendix Table 2. Characteristics of Residents, Adjusted for Non-Response and Questionable Answers

\begin{tabular}{|c|c|c|c|c|}
\hline & $\begin{array}{l}\text { Recent } \\
\text { movers }\end{array}$ & $\begin{array}{l}\text { Residents who } \\
\text { stayed longer }\end{array}$ & $\begin{array}{l}\text { Long-distance } \\
\text { Movers }\end{array}$ & $\begin{array}{c}\text { Short-distance } \\
\text { Movers }\end{array}$ \\
\hline & \multicolumn{2}{|c|}{ (Table 3) } & \multicolumn{2}{|c|}{ (Table 5) } \\
\hline \multicolumn{5}{|l|}{ Gender } \\
\hline Male & $35.8 \%$ & $30.3 \%$ & $69.4 \%$ & $69.7 \%$ \\
\hline \multicolumn{5}{|l|}{ Race } \\
\hline White & $99.7 \%$ & $99.8 \%$ & $98.1 \%$ & $97.1 \%$ \\
\hline \multicolumn{5}{|l|}{ Marital Status } \\
\hline Married & $22.0 \%$ & $14.1 \%$ & $14.7 \%$ & $15.1 \%$ \\
\hline \multicolumn{5}{|l|}{ Education } \\
\hline College educated & $34.0 \%$ & $31.0 \%$ & $35.4 \%$ & $30.9 \%$ \\
\hline \multicolumn{5}{|l|}{ Health } \\
\hline Self rated excellent or very good & $33.8 \%$ & $31.5 \%$ & $36.6 \%$ & $31.0 \%$ \\
\hline Same/better compared to two years ago & 47.5 & 53.6 & 30.2 & 38.9 \\
\hline Received assistance before moving in & 46.5 & 36.6 & 30.0 & 38.6 \\
\hline \multicolumn{5}{|l|}{ Prior living arrangement } \\
\hline Living in another community & $31.6 \%$ & $26.7 \%$ & $34.0 \%$ & $25.2 \%$ \\
\hline \multicolumn{5}{|l|}{ Expenses covered by current income } \\
\hline All of the expenses & $42.6 \%$ & $35.6 \%$ & $42.6 \%$ & $35.6 \%$ \\
\hline Most of the expenses & 24.3 & 29.6 & 24.3 & 29.6 \\
\hline Some of the expenses & 27.0 & 29.7 & 27.0 & 29.7 \\
\hline None of the expenses & 6.1 & 5.2 & 6.1 & 5.2 \\
\hline \multicolumn{5}{|l|}{ Relative to my ability to afford the fees } \\
\hline No concern & $35.4 \%$ & $29.2 \%$ & $35.4 \%$ & $29.2 \%$ \\
\hline Some concern & 40.6 & 47.1 & 38.7 & 44.4 \\
\hline Considerable concern & 24.0 & 23.8 & 22.9 & 22.4 \\
\hline \multicolumn{5}{|l|}{ Total net worth (in thousands) } \\
\hline$<\$ 50$ & $27.9 \%$ & $28.9 \%$ & $25.3 \%$ & $30.4 \%$ \\
\hline$\$ 50-\$ 100$ & 13.0 & 13.3 & 10.5 & 13.9 \\
\hline$\$ 100-\$ 300$ & 22.7 & 20.5 & 19.4 & 20.4 \\
\hline$\$ 300-\$ 500$ & 11.8 & 11.7 & 13.7 & 11.4 \\
\hline$\$ 500-\$ 750$ & 9.6 & 8.9 & 10.2 & 8.6 \\
\hline$\$ 750-\$ 1,000$ & 7.8 & 6.6 & 6.5 & 6.9 \\
\hline$\$ 1,000-\$ 2,000$ & 3.4 & 6.3 & 8.1 & 5.5 \\
\hline$\$ 2,000+$ & 3.7 & 3.8 & 6.3 & 2.9 \\
\hline
\end{tabular}

Source: Authors' calculations of the Residents' Financial Survey. 


\section{RECENT WORKING PAPERS FROM THE CENTER FOR RETIREMENT RESEARCH AT BOSTON COLLEGE}

Costs and Concerns among Residents in Seniors Housing and Care Communities: Evidence from the Residents Financial Survey

Norma B. Coe and April Yanyuan Wu, April 2012

Financial Well-Being of Residents in Seniors Housing and Care Communities: Evidence from the Residents Financial Survey

Norma B. Coe and April Yanyuan Wu, April 2012

Residents in Senior Housing and Care Communities: Overview of the Residents Financial Survey

Norma B. Coe and April Yanyuan Wu, April 2012

Social Security Claiming: Trends and Business Cycle Effects

Owen Haaga and Richard W. Johnson, February 2012

Economic Consequences of the Great Recession: Evidence from the Panel Study of Income Dynamics

Barry Bosworth, February 2012

The Changing Causes and Consequences of Not Working Before Age 62

Barbara A. Butrica and Nadia Karamcheva, February 2012

The Impact of Temporary Assistance Programs on Disability Rolls and Re-Employment Stephan Lindner and Austin Nichols, January 2012

Understanding the Growth in Federal Disability Programs: Who Are the Marginal Beneficiaries, and How Much Do They Cost?

Adele Kirk, January 2012

What Explains State Variation in SSDI Application Rates?

Norma B. Coe, Kelly Haverstick, Alicia H. Munnell, Anthony Webb, December 2011

How Do Subjective Mortality Beliefs Affect the Value of Social Security and the Optimal Claiming Age?

Wei Sun and Anthony Webb, November 2011

How Does the Personal Income Tax Affect the Progressivity of OASI Benefits?

Norma B. Coe, Zhenya Karamcheva, Richard Kopcke, Alicia H. Munnell, November 2011

All working papers are available on the Center for Retirement Research website

(http://crr.bc.edu) and can be requested by e-mail (crr@bc.edu) or phone (617-552-1762). 